\title{
Public support for the social rights and social obligations of the unemployed: Two sides of the same coin?
}

Laenen T., Meuleman B. Public support for the social rights and social obligations of the unemployed: Two sides of the same coin?

In light of the ever-growing shift towards activation in European welfare states, the present article examines the relationship between citizens' welfare generosity (i.e., support for social rights) and welfare conditionality (i.e., support for social obligations) with regard to the unemployed. Using data from the 2014 Belgian National Elections Study, we found that generosity and conditionality appear to be two sides of the same coin. The two factors are negatively correlated, and most of their respective attitudinal drivers are quite similar in strength, yet opposite in direction. In addition to self-interest and conventionally recognised ideational beliefs, such as egalitarianism and individualism, beliefs about welfare deservingness - an explanatory factor that has remained understudied in the field - are particularly influential in shaping people's welfare preferences. A stronger emphasis on criteria of deservingness such as control, attitude and reciprocity considerably lowers support for social rights and strengthens support for social duties.

\author{
Tijs Laenen (iD, Bart Meuleman \\ Centre for Sociological Research, Leuven, Belgium
}

Key words: public opinion, unemployment insurance, social rights, social obligations, welfare deservingness, Belgium

Tjis Laenen, Centre for Sociological Research, KU Leuven, Parkstraat 45, Box 3601, 3000 Leuven, Belgium, Tel: +32 16 374423

E-mail: tijs.laenen@kuleuven.be

Accepted for publication 22 0ctober 2018

\section{Introduction}

Since the 1980 s, the financial sustainability and social legitimacy of various social protection policies have been scrutinised under the impetus of successive economic recessions, various migration flows and an ageing population (Taylor-Gooby, 2011). The argument that social benefits are a burden for the national economy and produce lazy, dependent citizens has become widespread in public debates on the pros and cons of social security (Murray, 1984; van Oorschot, Reeskens, \& Meuleman, 2012). A popular policy response to this critique has been the implementation of activation measures incorporating a quid pro quo principle. Across Europe, social obligations are increasingly being imposed on benefit recipients as a way to counterbalance social rights (Betzelt \& Bothfeld, 2011; Kvist, 2002). Belgium, the national context in which the present study is embedded, is perhaps somewhat exceptional, as its 'reluctant and erratic path toward activation' (Hemerijck \& Marx, 2010, p. 139) means it has lagged behind in this regard. However, in recent years the Belgian welfare state appears to have been catching up, as jobless people are now required to show willingness to work by actively searching for employment, participating in training courses or engaging in work experience programmes in order to continue receiving payments provided by unemployment insurance or social assistance. Further, new ways in which the unemployed should reciprocate are regularly being suggested in political discourse and in the popular media.

Despite the growing trend towards activation in welfare states, relatively little is known about its social legitimacy, as most previous research has approached the issue from a social rights perspective (van Oorschot \& Roosma, 2017). The few existing studies dealing with social obligations have shown that there is widespread support among the general public for imposing work-related obligations on recipients of unemployment benefits (Buss, Ebbinghaus, \& Naumann, 2017; Houtman, 1997; Jeene \& van Oorschot, 2015; Larsen, 2008; Saunders, 2002). In trying to explain support for social obligations, most scholars have largely followed social rights literature in identifying material self-interest and ideational beliefs as the two most crucial explanatory factors. The effects of these individual-level determinants are commonly expected to run in opposite directions, however, thereby implicitly suggesting a negative relationship between welfare generosity (i.e., the extent to which citizens favour social rights) and welfare conditionality (i.e., the degree to which citizens support social obligations). 
In this article, these frequently studied predictors are supplemented by an empirically less established framework that is highly relevant for understanding welfare state legitimacy: deservingness theory (van Oorschot, 2006; van Oorschot \& Roosma, 2017). The importance individuals attach to certain deservingness criteria not only has the potential to shape support for social rights, but also speaks directly to the conditions benefit recipients need to fulfil to be considered as deserving of social welfare (Larsen, 2006, 2008). Accordingly, this article contributes to existing literature, first by examining systematically whether welfare conditionality and welfare generosity are indeed two sides of the same coin, driven by the same explanatory factors but working in opposite directions, and second by investigating the impact of deservingness beliefs on support for social rights and social obligations. For this purpose, we analysed survey data from the 2014 Belgian National Elections Study (Abts et al., 2015).

The article is divided into four sections. The first reviews the relevant literature and formulates specific hypotheses about the role of self-interest and various ideational beliefs - including deservingness opinions - in shaping public support for the social rights and obligations of the unemployed. The second describes the methodology that was used to test these hypotheses. The third section analyses how conditionality and generosity are associated, and which attitudinal drivers are important in shaping both types of welfare attitudes. The last section concludes and raises some points of discussion that require further investigation.

\section{Theory and hypotheses}

In recent decades, social security systems that protect citizens from the vicissitudes in life that impede the acquisition of a market income (e.g., job loss, old age, sickness) have been increasingly criticised for their one-sided focus on social rights. Social protection is assumed to create and foster lazy, statedependent citizens, and activation policies are being proposed and implemented as a cure for this alleged passivity problem endangering the welfare state. Although 'activation' has become an umbrella term covering a broad array of divergent policy measures, a common factor underlying many (but by no means all) of them is the imposition of social obligations on individual (unemployed) welfare recipients as a way to counterbalance their social rights (Betzelt \& Bothfeld, 2011; Kvist, 2002). We acknowledge that many activation policies do not impose obligations on individuals because in many cases they are either voluntary in nature (e.g., training courses offered to unemployed people) or directed at employers instead of individuals (e.g., wage subsidies for hiring people in high-unemployment risk categories). However, the focus of this article is on popular attitudes towards activation policies that incorporate individual obligations. Which social-structural and ideational factors are related to people's welfare conditionality, and to what extent are they similar to those associated with people's welfare generosity?

A long-standing and well-established idea in welfare legitimacy research is that welfare attitudes are driven by two distinct yet interrelated mechanisms: material self-interest and ideational beliefs (Hasenfeld \& Rafferty, 1989; Jaeger, 2006; Kangas, 1997). In the self-interest logic, citizens are essentially calculating creatures seeking to maximise gain and limit pain, and welfare opinions reflect people's rational interests. According to this argument, socioeconomic groups that are at the greatest risk of needing state support should be the strongest advocates of generous welfare provision. Most empirical research indeed shows that the strongest supporters of welfare allocation are found among people on low incomes, benefit recipients, the lower educated, the older-aged, the unemployed, ethnic minorities and women (Alston \& Dean, 1972; Arts \& Gelissen, 2001; Bean \& Papadakis, 1998; Cusack, Iversen, \& Rehm, 2006; Linos \& West, 2003). The self-interest logic can also be applied to support for making access to welfare conditional on fulfilment of certain social obligations. Because socially vulnerable groups might fear they will be the ones who will have to fulfil the obligations and potentially lose their benefits (Jeene \& van Oorschot, 2015), they will be the most sceptical of activation policies. Previous empirical studies support the claim that opposition to activation policies is strongest among people in socially risky positions (Eardley, Saunders, \& Evans, 2000; Furaker \& Blomsterberg, 2003; Houtman, 1997; Larsen, 2008; Saunders, 2002).

Prior research, however, has often ignored the fact that motives based on self-interest are contingent on the specific social risk under consideration, as well as on the broader context of the society in which people live. It is generally assumed, for example, that pensioners are among the strongest proponents of generous and unconditional welfare provision because of their vulnerable position in society. Yet from a self-interest perspective, it is unclear why pensioners should be concerned about the specific risk of unemployment, as they are no longer assumed to be active in the labour market and thus have no direct personal stake in unemployment benefits. Accordingly, the present study incorporates the self-interest perspective by identifying those social-structural groups that 
are most vulnerable in the Belgian labour market, and have the greatest personal interest in supporting generous and unconditional unemployment benefits. According to the International Monetary Fund, the Belgian labour market is highly segmented along four dimensions: age, skills, ethnic background and region. First, the level of unemployment is structurally much higher among young adults than it is among middle-aged people. In 2014 (during the period of data collection), the unemployment rate was $15.6 \%$ among young adults between 20 and 29 years of age, compared with $6.8 \%$ among persons between 30 and 54 (Statistics Belgium, 2014). Furthermore, in a 2013 royal decree, the Belgian government recognised people older than 50 as a high-risk group. The underlying logic is that persons over 50 often encounter disproportionate difficulties in finding a new job, which is manifested in longer spells of unemployment. Second, education is considered an important factor in the contemporary knowledge-based Belgian labour market. Unemployment levels are structurally much higher among the lower educated $(16.4 \%$ in $2014)$ than the medium (8.8\%) and higher educated (4.7\%). Third, a person's ethnic background remains a tenacious determinant of unemployment risk in Belgium. In 2014, unemployment was considerably more prevalent among non-EU immigrants (23.4\%) than among EU immigrants (10.4\%) and native-born (6.6\%). Lastly, the unemployment level in the Frenchspeaking region of Belgium has been much higher in recent years than in the Dutch-speaking region $(11.7 \%$ in Wallonia, compared with $4.9 \%$ in Flanders in 2014).

For these reasons, we distinguished five social categories in Belgium that are facing a disproportionally high risk of unemployment: the lower educated, people between 18 and 26 years of age, those between 50 and 65 , ethnic minorities and people living in Wallonia. In addition to risk exposure, the actual realisation of the risk of unemployment among the working-age jobless or disabled persons is also an important self-interest motivation for supporting social rights and opposing social obligations more strongly (Cusack et al., 2006). Because persons who are permanently outside the labour market, such as pensioners, have no clear-cut personal stake in state-provided unemployment insurance, they are expected to be either less generous and more conditional towards the unemployed compared with persons in the labour market, or to be similar to the general population. We did not expect gender to be an important predictor of attitudes towards unemployment provision, as the unemployment rates among men and women in Belgium do not differ notably. Based on the preceding discussion of labour market vulnerability, the self-interest hypothesis predicts that: People who are currently unemployed/ disabled, or exposed to a higher risk of unemployment (i.e., the lower educated, people between 18 and 26 years of age, those between 50 and 65, ethnic minorities and people living in Wallonia) are more generous (Hla) and less conditional $(\mathrm{Hl} b)$ towards the unemployed.

According to a second well-established line of reasoning, welfare policy preferences also reflect the general ideational beliefs people hold. In the established social rights literature as well as in the emerging social obligations literature, egalitarianism, individualism, left-right ideology and work ethic are claimed to be particularly influential, yet these conventionally recognised belief systems are assumed to have opposing effects on support for social rights and support for social obligations. The endorsement of egalitarian ideals is associated with higher levels of welfare generosity (Feldman \& Zaller, 1992; Likki \& Staerklé, 2015; Svallfors, 2013) and lower levels of welfare conditionality (Achterberg, van der Veen, \& Raven, 2014; Houtman, 1997). By contrast, adherence to individualism, a right-wing political stance and a strong belief in the virtue of hard work and diligence temper support for social rights (Bean \& Papadakis, 1998; Feldman \& Zaller, 1992; Gilens, 1999; Jaeger, 2006, 2008; Jeene \& van Oorschot, 2013) and stimulate support for conditionality (Eardley et al., 2000; Jeene \& van Oorschot, 2015; Larsen, 2008; Saunders, 2002). Therefore, the conventional ideational hypothesis anticipates that: People who adhere to anti-egalitarian, individualistic or politically right-wing ideals, or have a strong work ethic, are less generous $(H 2 a)$ and more conditional $(\mathrm{H} 2 \mathrm{~b})$ towards the unemployed.

Although these conventional ideational beliefs might seem to come conceptually close - perhaps even too close - to generosity and conditionality, our argument for treating them as different constructs is twofold. First, we make the case that the ideological beliefs under consideration here are theoretically distinct from our dependent variables. For example, egalitarianism and generosity are not, as some might argue, one and the same thing, because egalitarians are not necessarily supporters of state welfare and vice versa. People who strive for a more equal society might consider institutions other than the welfare state as more appropriate for establishing that equality, such as the family or private charity. Likewise, people who favour generous welfare provision might do so for reasons other than a desire to create a more equal society, such as income maintenance or poverty alleviation. Second, there is the level of abstraction: While the ideological beliefs pertain to the broader society, generosity and 
conditionality as conceptualised here refer only to the particular group of unemployed people. Within the welfare attitudes literature, it is well-accepted standard practice to explain such specific policy preferences by more general ideological beliefs (Bean \& Papadakis, 1998; Feldman \& Zaller, 1992; Hasenfeld \& Rafferty, 1989; Svallfors, 2013). However, it should be noted that most of these studies, including the current one, make use of cross-sectional data, which hampers the disentanglement of cause and effect. In this article, it is assumed that the causal mechanism runs from ideational beliefs to policy preferences, but the possibility that it could also be the other way around is left open.

In addition to these 'usual suspects', beliefs about welfare deservingness are increasingly being recognised as crucial ideational factors that shape social policy preferences (Appelbaum, 2001; Kallio \& Kouvo, 2015; Kootstra, 2016; Larsen, 2006; Petersen, 2012; Slothuus, 2007; van Oorschot, 2006; van Oorschot \& Roosma, 2017). The main premise is that people's welfare generosity towards particular target groups is a function of the importance they attach to the five socalled 'CARIN criteria' (see below) in judging who should get what from the welfare state, and further, how they evaluate target groups on these deservingness criteria based on their (perceived) group characteristics (van Oorschot \& Roosma, 2017). In short, target groups that are perceived to have little personal control over their predicament (Control), are grateful and docile (Attitude), have made adequate contributions to society (Reciprocity), belong to one's in-group (Identity) ${ }^{1}$ and have high financial needs (Need), are generally judged to be highly deserving of generous welfare support. In a similar vein, the few studies that have paid attention to the link between deservingness and welfare conditionality have noted that some specific policy target groups (e.g., disabled persons) are granted more leniency in fulfilling work obligations than other groups (e.g., unemployed persons), because the public evaluates these groups more favourably on the deservingness criteria (Jeene \& van Oorschot, 2015; Larsen, 2006; Roosma \& Jeene, 2017). As the somewhat negative stereotypical image of the lazy, non-contributing, fraudulent and ungrateful unemployed appears to be pervasive among large sections of the European public (Furnham, 1983; Furaker \& Blomsterberg, 2003; Larsen, 2002; Maassen \& De Goede, 1989), this specific target group is presumably evaluated particularly poorly on the criteria of control, reciprocity and attitude (van Oorschot, 2006). As a consequence, people who emphasise these criteria are

\footnotetext{
1 Because the dataset does not provide a meaningful operationalisation of the identity criterion, we do not specify the anticipated effect of this criterion on people's generosity and conditionality towards the unemployed.
}

likely to be less generous and more conditional towards the jobless. Giving weight to the need criterion might have the opposite effect, as previous research has shown that Europeans believe the unemployed have a relatively low standard of living, or in other words, have a high level of need (van Oorschot \& Meuleman, 2012). In sum, the deservingness hypothesis predicts that: People who strongly emphasise the deservingness criteria of control, attitude and reciprocity, or attach little importance to the need criterion, are less generous $(H 3 a)$ and more conditional $(H 3 b)$ toward the unemployed.

The foregoing literature review and subsequent hypotheses suggest that welfare conditionality and welfare generosity are both shaped by self-interest and ideational beliefs, but in opposite ways, and accordingly seem to be two sides of the same coin. Previous empirical work partly confirms and partly nuances this premise. While Roosma and Jeene (2017) reported a negative relationship between opinions about the rights and obligations of welfare claimants among the Dutch population, Jeene and van Oorschot (2015) showed that Dutch citizens are scattered over four attitudinal patterns concerning the preferred rights obligations balance. Nearly half of the Dutch public (49.2\%) appeared to either want high social rights combined with low social duties for the unemployed ('unconditional generosity'), or low rights coupled with high obligations ('work first'). However, among the remaining Dutch population, social rights and social duties were not necessarily seen as opposites, as most $(44.2 \%)$ preferred both high rights and high duties ('conditional generosity') and only some (6.6\%) were strongly opposed to both rights and obligations ('laissez-faire'). Based on these studies, and the assumption that self-interest and ideational beliefs are influential attitudinal drivers - the impact of which on generosity and conditionality runs in opposite directions - a fourth 'two sides of the same coin' hypothesis predicts that: There is a negative correlation between welfare generosity and welfare conditionality $(\mathrm{H} 4)$.

To summarise, the four theoretical hypotheses of the present study are graphically illustrated in the conceptual model presented in Figure 1 below.

\section{Data and methods}

\section{Dataset}

The theoretical hypotheses were tested using data from the 2014 Belgian National Elections Study (Abts et al., 2015), which is a general population survey administered among a probability sample of Belgian residents entitled to vote. The survey consisted of faceto-face interviews $(N=1,901$, response rate $=47.5 \%)$ and a drop-off, self-completion questionnaire left at the respondents' home by the interviewer $(N=1,403$, 


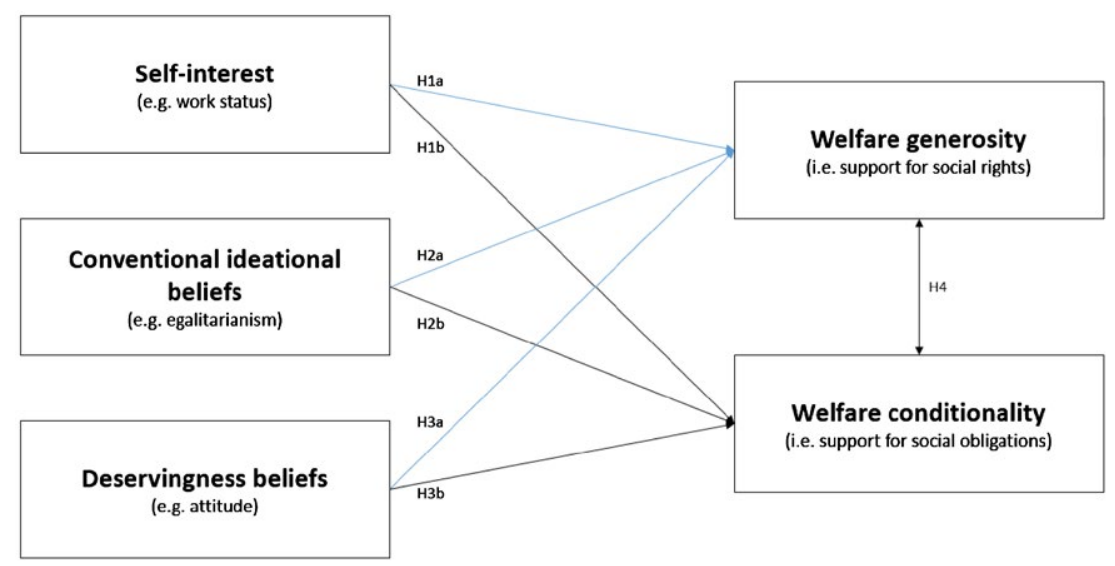

Figure 1. Conceptual model - a negative correlation between welfare generosity and conditionality, induced by contrasting effects of ideational beliefs and self-interest.

participation rate $=73.8 \%$ ). Because some indicators of particular interest for the present study were assessed in the drop-off questionnaire (e.g., the attitude criterion), the subsequent analyses included only those respondents who took part in both waves. To correct for a compositional mismatch between the sample and the population, post-stratification weighting for age, gender and educational level was applied.

\section{Dependent variables}

Welfare generosity was measured by a single item asking to what extent the (Belgian) government should, on a scale from 0 to 10 , take responsibility for providing a decent standard of living for the unemployed, with higher scores indicating a stronger acceptance of social rights. Welfare conditionality was measured as the average of three Likert-type statements (5-point agree-disagree scale): (a) The long-term unemployed should be obliged to accept any job, even if they earn much less than before by doing so; (b) People on social assistance should be obliged to do community work; and (c) The long-term unemployed should be obliged to re-educate themselves, otherwise they would lose their social benefits. Higher scores on the resulting additive scale variable $(\alpha=0.645)$ suggest stronger approval of imposing social obligations. Confirmatory Factor Analysis (CFA; see Appendix) furthermore showed that these items can be considered as valid and reliable indicators of the intended concepts.

\section{Independent variables}

People's material self-interest was indirectly gauged through a number of respondents' social-structural characteristics. First, age-related unemployment risk was based on a combination of age and work status, and comprised six categories: a young, employed adult higher-risk group (18-30 years old); a middle-aged, employed lower-risk group (31-49); a pre-retirement, employed higher-risk group (50-64); a retired non-risk group (mostly $65+)^{2}$; a realised risk group (unemployed/disabled persons); and a residual category consisting mainly of students and homemakers. Educational level has three categories: lower secondary or below, higher secondary, and tertiary. Past benefit receipt measures whether someone in the respondent's household had received welfare benefits, such as social assistance, unemployment benefits or disability benefits, in the two years prior to the data collection. Ethnic background was operationalised by the father's place of birth (Belgium, inside the EU or outside the EU) instead of that of the respondents, so that we could also include second-generation migrants, who still have a disadvantaged position in the Belgian labour market. Gender was included as a control variable.

With regard to ideational beliefs, left-right ideology was assessed by means of self-placement on a scale ranging from 0 ('very left-wing') to 10 ('very right-wing'). The remaining ideational beliefs were measured by averaging respondents' scores across multiple Likert-type items ranging from 1 ('completely disagree') to 5 ('completely agree'). Egalitarianism $(\alpha=0.675)$ was operationalised by means of the following three statements: (a) The differences between classes ought to be smaller than they are at present; (b) The differences between high and low incomes should stay as they are [reverse coded]; and (c) The government should reduce income differentials. Individualism $(\alpha=0.747)$ was calculated as the mean score over three indicators: (a) Humanity, brotherhood and solidarity are all nonsense, everybody has to take care of him/ herself first; (b) Striving for personal success is more

2 The non-risk pensioner category also included those aged
between 55 and 64 years who took early retirement $(n=63)$. 
important than providing for good relations with your fellow man; and (c) In our society everything revolves around one's own interest, power and material success. That is why it is better to take care first and foremost of oneself. Work ethic $(\alpha=0.620)$ was assessed by four items: (a) To completely develop your talents, you need a job; (b) It is embarrassing to receive money without having had to work for it; (c) Work is a duty towards society; and (d) Work should always come first, even if it means less leisure time. CFA (see Appendix) showed that these items form reliable scales capturing the latent belief systems in their various dimensions. This CFA also confirmed that the ideational dimensions have sufficiently strong discriminant validity: The correlations between the various latent variables (including dependent variables) never exceeded 0.60 . As a result, the latent concepts only overlapped very partially, and could be clearly distinguished from one another.

With regard to welfare deservingness, most previous studies have tried to measure this by using either traditional survey items that tap into respondents' perceptions of different policy target groups, or vignette experiments that assess the impact of randomly varied welfare recipient characteristics on respondents' generosity towards those recipients. However, as 'an agreed-upon instrument or procedure to measure deservingness opinions is [still] lacking at present' (Meuleman, Roosma, \& van Oorschot, 2017, p. 350), we employed another, novel way to operationalise deservingness opinions. Specifically, we used survey items that gauge the importance people attach to abstract deservingness criteria, not only in relation to one particular vignette recipient or policy target group, but to social security more in general. People's emphasis on the control criterion $(\alpha=0.605)$ was calculated as the average score across two items: (a) People who fall into poverty because of their own mistakes should be entitled to social assistance [reverse coded]; and (b) People who have themselves to blame for their problems do not deserve any support from social security. Scores for the attitude criterion $(\alpha=0.660)$ were calculated as the mean score over two items: (a) People receiving social benefits should show more gratitude; and (b) People on social assistance should be pleased about this and do not have any right to complain. Reciprocity $(\alpha=0.796)$ was operationalised using five items: (a) Social security should be preserved for those who have contributed to collective prosperity; (b) It is not fair that people receive social benefits to which they have not contributed; (c) Only people who work are entitled to government social services; (d) People who have worked and contributed in the past deserve better social services than people who have contributed little or nothing; and (e) It is unfair that people contribute to social services they don't use. Lastly, the importance people attach to the criterion of need $(\alpha=0.732)$ was operationalised as the mean score over three items: (a) Social security should only be available to those who truly live in poverty, (b) People with sufficient financial resources should not receive social benefits, and (c) Only people in dire need should receive social benefits. Unfortunately, the data lack items to adequately measure the extent to which respondents gave weight to the criterion of identity. The measurement quality of these scales was also confirmed by CFA (see Appendix).

\section{Statistical modelling}

To test our hypotheses, we used step-wise, ordinary least squares regression to explain welfare generosity and welfare conditionality. The first step (A models) regressed the dependent variables on social-structural indicators. In the subsequent step, the four conventional ideational beliefs (egalitarianism, individualism, left-right ideology, work ethic; B models) and the empirically less-established deservingness criteria $(\mathrm{C}$ models) were added. This approach takes into account that ideational and deservingness beliefs can be informed by social-structural characteristics: While the A models provide the total effects of social structure (direct as well as indirect via the beliefs), the B and C models show the social-structural effects controlling for the relevant beliefs.

\section{Results}

Descriptive results: support for social rights and obligations in the Belgian population

We start by describing the distribution of welfare generosity and conditionality. Figure 2 shows that both have their peak higher than the midpoint of the scale. On average, public support for social rights is 6.63 $(\mathrm{SD}=2.25)$ on a scale ranging from 0 to 10 , and popular support for social obligations is $3.68(\mathrm{SD}=0.73)$ on a scale from 1 to 5 . The Belgian public is therefore reasonably supportive of government intervention in favour of the unemployed, yet at the same time also favours placing conditions on them. The relatively widespread agreement among Belgians that unemployment benefits ought to be generous but also conditional on the fulfilment of a number of work-related obligations is in line with previous studies conducted in other countries (Buss et al., 2017; Eardley et al., 2000; Houtman, 1997; Jeene \& van Oorschot, 2015; Larsen, 2008; Saunders, 2002).

\section{Explaining people's welfare generosity and conditionality}

Models 1a and 2a in Table 1 - regressing people's welfare generosity and conditionality, respectively, on a number of social-structural indicators - provide 

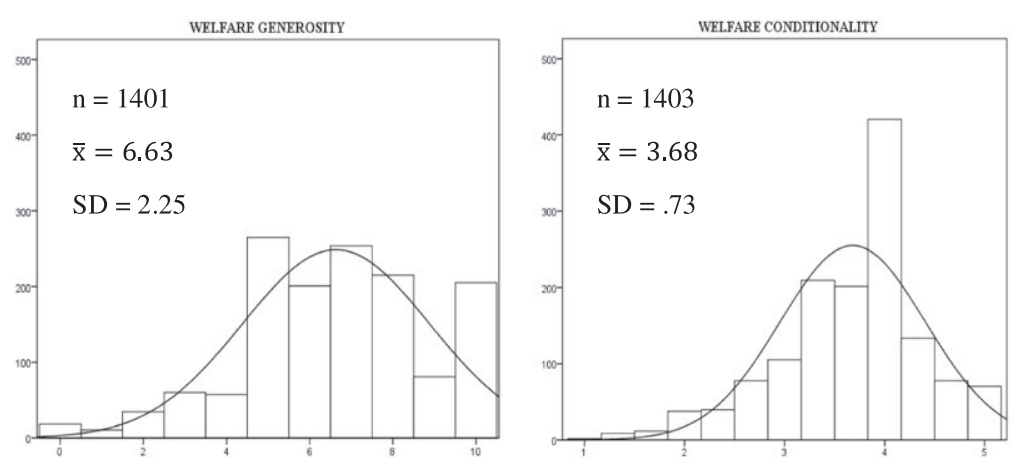

Figure 2. Absolute frequency distribution of welfare generosity and welfare conditionality.

some evidence for the self-interest hypotheses (HIa and $H 1 b$ ). Certain vulnerable social categories - such as the unemployed/disabled, benefit recipients, those with a father born outside of the EU, the lower educated and those living in the high-unemployment region of Wallonia - appear to be significantly more generous. Being currently unemployed/disabled and receiving benefits clearly weakens support for social obligations. However, a self-interest interpretation of these findings is, at the same time, challenged by the fact that: (1) pensioners are considerably more generous towards the unemployed despite being permanently outside the labour market, (2) higher-educated individuals are less conditional and more generous despite having a relatively secure position in the labour market, and (3) the high-risk groups of younger and older employees do not significantly differ from their lower-risk counterparts of middle-aged employees in their support for both social rights and obligations. When the conventional ideational beliefs were added to the regression models (see Models $1 \mathrm{~b}$ and $2 \mathrm{~b}$ in Table 1 ), most associations between social-structural position and our dependent variables remained fairly similar, albeit with some exceptions. It was only when ideational factors were taken into account that: (1) the higher levels of generosity found among benefit recipients and the higher educated disappeared, and (2) gender turned into a significant predictor of welfare conditionality. In line with previous research (Larsen, 2008; Saunders, 2002), women proved to be more conditional than men in their solidarity with the unemployed. These findings suggest that the effect of social position on welfare generosity and conditionality towards the unemployed is to some extent mediated by ideological beliefs (see also, e.g., Hasenfeld \& Rafferty, 1989). With regard to the impact of ideational beliefs, the results show that adherence to individualism, a right-wing political ideology or a strong work ethic lowers support for social rights (as predicted by $\mathrm{H} 2 \mathrm{a}$ ) and strengthens support for the social obligations of the unemployed $(H 2 b)$, while valuing egalitarianism has the opposite effect. However, whereas work ethic appears to be most decisive in driving welfare conditionality, egalitarianism is most important in shaping welfare generosity.

Next, welfare deservingness beliefs were added to the models. Model 1c shows that emphasising deservingness criteria consistently lowers support for the social rights of the unemployed, which means that citizens expecting sufficient gratitude, adequate contributions and a lack of personal responsibility from social security recipients also feel that the state should be less generous towards the unemployed. For the need criterion, however, this negative relationship was neither statistically nor substantially significant, which could be due to the widely accepted perception that unemployed people have a relatively low standard of living, or in other words, are confronted with a high level of neediness (van Oorschot \& Meuleman, 2012). Although including welfare deservingness beliefs led to only a minor increase in the explained variance of welfare generosity (as illustrated by a 0.030 increase in $\mathrm{R}_{\mathrm{a}}^{2}$ ), the effects of the deservingness criteria did seem to overrule those of most of the conventional ideational beliefs (i.e., individualism, work ethic and left-right ideology). By contrast, the positive association between welfare generosity and egalitarianism remained almost equally strong and stable.

As displayed in Model 2c, emphasising the deservingness criteria (excepting the need criterion) also appears to significantly strengthen support for imposing social obligations on the unemployed, leading to a substantial increase in the proportion of explained variance (a 0.104 rise in $\mathrm{R}^{2}$ a compared with Model 2a). The attitude criterion is clearly most influential in this regard: People who attach greater importance to this criterion might regard the fulfilment of social obligations as a way in which social security recipients can demonstrate their gratitude. Likewise, people who stress reciprocity might be more conditional because the activating welfare state is seen to offer 


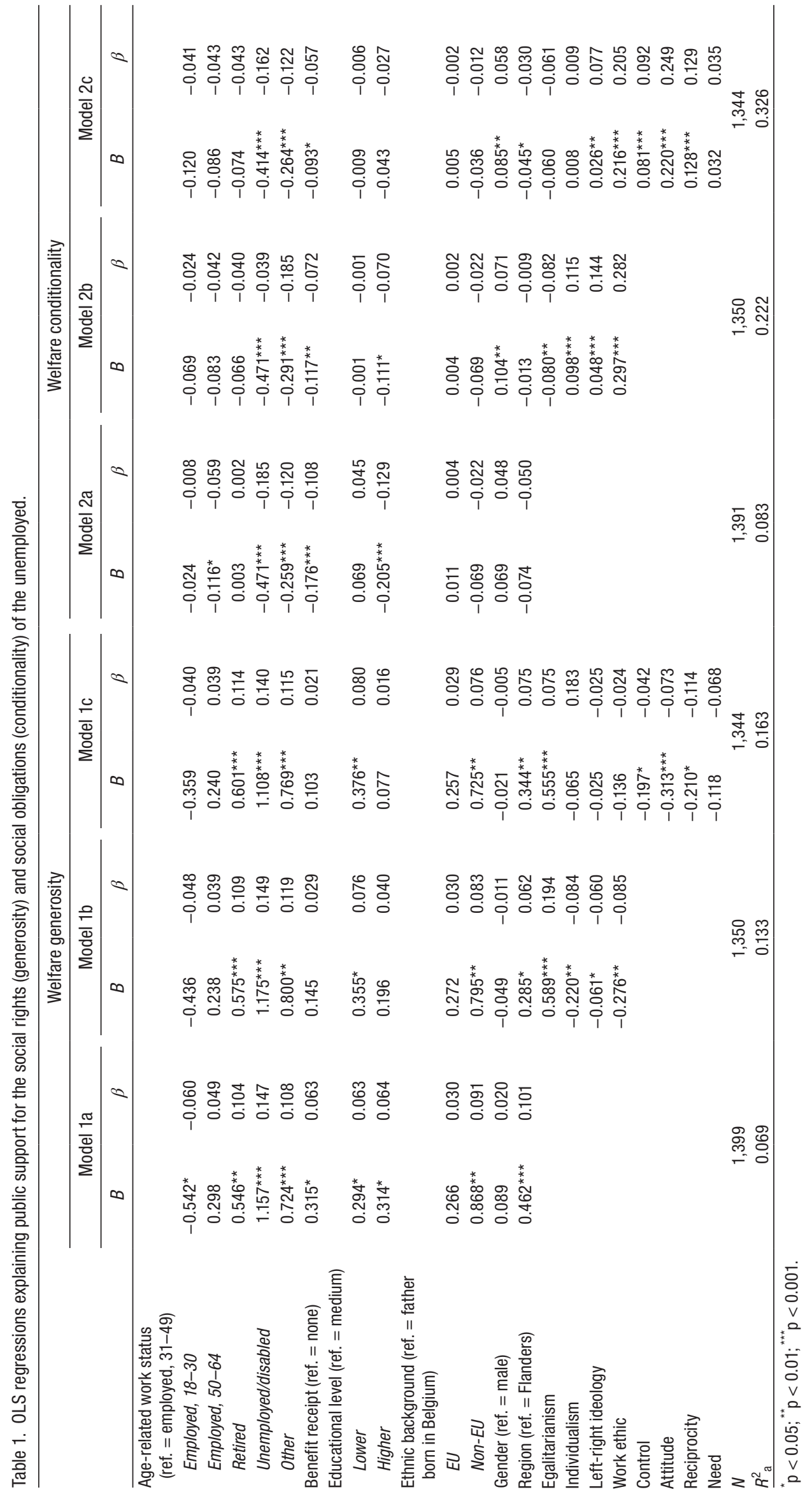


unemployed persons novel opportunities to contribute. People emphasising the criterion of control might, in turn, consider social duties to be a fair type of sanction for persons who are presumed to be willingly unemployed. Once more, the effects of the conventional ideational beliefs of egalitarianism, individualism and, to a lesser extent, left-right ideology and work ethic diminished after including deservingness beliefs. Taken together, the analyses broadly support the deservingness hypotheses, stating that emphasising the criteria of deservingness lowers people's welfare generosity ( $H 3 a)$ while strengthening their support for welfare conditionality $(H 3 b)$. However, the stronger effects of the deservingness criteria on conditionality suggest that the deservingness framework sheds considerably more light on people's opinions about social obligations than it does on attitudes towards social rights.

\section{The correlation between welfare generosity and conditionality}

The final step illustrates that there is a statistically significant and substantially moderate negative association between generosity and conditionality $(r=-0.312$, $n=1,390, \mathrm{p}<0.01$ ), which means that high levels of support for social rights tend to coincide with relatively weak support for social obligations, and vice versa. This finding clearly supports the "two sides of the same coin' hypothesis (H4). The regression models presented in the previous section suggest that the opposing attitudinal drivers of self-interest, conventional ideational beliefs and deservingness beliefs are presumably responsible for this negative relationship.

\section{Conclusion and discussion}

In light of the ever-growing shift towards activation in European welfare states, this study examined the relationship between citizens' welfare generosity (i.e., support for social rights) and welfare conditionality (i.e., support for social obligations) toward the unemployed. Based on data from the 2014 Belgian National Elections Study, the main conclusion is that generosity and conditionality appear to be two sides of the same coin for two reasons. First, a statistically and substantially significant negative association between both types of welfare attitudes was found, a correlation that had previously also been detected in the Netherlands (Roosma \& Jeene, 2017). Although such comparable findings in two fairly different welfare states suggest that the 'two sides of the same coin' thesis is not merely confined to the Belgian context, future crossnational research should examine its generalisability in more detail.

The second reason is that, as demonstrated in Table 2, most of the attitudinal drivers are similar in strength yet opposite in direction. Three types of influential drivers were deduced from existing welfare attitudes literature: self-interest (captured by social-structural indicators), conventionally recognised ideational beliefs such as egalitarianism and individualism, and relatively understudied welfare deservingness beliefs. We found some evidence in favour of the self-interest thesis which posits that people in a weaker socioeconomic position (e.g., the unemployed/ disabled) are more generous and less conditional towards the unemployed. However, two findings in particular contradict the self-interest argument. First, the higher educated were found to be less conditional, despite having a more secure position in the Belgian labour market. Though this may seem to conflict with their interests, a closer look at one of the specific social obligations under consideration might call this into question. That is, being obliged to accept any paid job, regardless of the pay level, is something that the higher educated in particular want to avoid, as they stand to lose most from such a policy. Second, despite being permanently outside the labour force, pensioners are more generous towards the unemployed than are middle-aged, employed people. A possible explanation is that today's pensioners demand stronger state involvement in terms of social welfare because they grew up in a day and age when the Belgian welfare state was not as elaborate as it is nowadays - a situation they would rather not return to. The last social-structural indicator that merits attention is gender, as women - perhaps somewhat counterintuitively, although corroborated by previous research (Larsen, 2008; Saunders, 2002) - proved to be more conditional than men towards the unemployed. Possibly the explanation is that women attach greater value to having work because of the struggle they went through to acquire the right to work and to establish more equal employment opportunities. However, future research is needed to delve more deeply into this gender gap in welfare conditionality.

The impact of the conventional ideational beliefs is in line with previous theoretical and empirical work. People who strongly adhere to the work ethic or have anti-egalitarian, individualist or politically right-wing ideas are less generous and more conditional regarding the unemployed. In addition to these conventionally recognised drivers of welfare attitudes, deservingness beliefs appear to be even more influential, particularly regarding opinions about social obligations. Placing emphasis on criteria of deservingness, such as control, attitude and reciprocity, considerably lowers support for social rights and strengthens acceptance of social obligations. Many of the conventional ideational beliefs lose much of their explanatory power once people's notions of welfare deservingness are taken into account. This makes it clear that deservingness beliefs are an indispensable factor to reckon with in welfare attitudes research. 
Table 2. A comparison of the impact of self-interest and ideational beliefs on welfare generosity and welfare conditionality.

\begin{tabular}{|c|c|c|}
\hline & $\begin{array}{c}\text { Welfare generosity } \\
\text { (i.e., support for social rights) }\end{array}$ & $\begin{array}{c}\text { Welfare conditionality } \\
\text { (i.e., support for social obligations) }\end{array}$ \\
\hline \multicolumn{3}{|c|}{ Self-interest indicators } \\
\hline \multicolumn{3}{|c|}{ Age-related work status (ref. = employed, $31-49$ years) } \\
\hline Employed, $18-30$ years & $-{ }^{\mathrm{ns}}$ & $-{ }^{\mathrm{ns}}$ \\
\hline Employed, $50-64$ years & $++^{\mathrm{ns}}$ & $-{ }^{\mathrm{ns}}$ \\
\hline Retired & + & $--^{\mathrm{ns}}$ \\
\hline Unemployed/disabled & + & - \\
\hline Other (e.g., homemaker, student) & + & - \\
\hline Benefit receipt (ref. = none) & $+^{\mathrm{ns}}$ & - \\
\hline \multicolumn{3}{|c|}{ Educational level (ref. = medium education) } \\
\hline Lower education & + & $-{ }^{\mathrm{ns}}$ \\
\hline Higher education & $t^{\mathrm{ns}}$ & $-{ }^{\mathrm{ns}}$ \\
\hline \multicolumn{3}{|c|}{ Ethnic background (ref. = father born in Belgium) } \\
\hline EU & $t^{\mathrm{ns}}$ & $t^{\mathrm{ns}}$ \\
\hline Non-EU & & $-{ }^{\mathrm{ns}}$ \\
\hline Gender (ref. = male) & $-{ }^{\mathrm{ns}}$ & + \\
\hline Region (ref. = Flanders) & + & - \\
\hline \multicolumn{3}{|l|}{ Ideational beliefs } \\
\hline Egalitarianism & + & $-{ }^{\mathrm{ns}}$ \\
\hline Individualism & $--^{\mathrm{ns}}$ & $++^{\mathrm{ns}}$ \\
\hline Left-right ideology & $-{ }^{\mathrm{ns}}$ & + \\
\hline Work ethic & $-{ }^{\mathrm{ns}}$ & + \\
\hline Control & - & + \\
\hline Attitude & - & + \\
\hline Reciprocity & - & + \\
\hline Need & $-{ }^{\mathrm{ns}}$ & $t^{\mathrm{ns}}$ \\
\hline
\end{tabular}

${ }^{*} \mathrm{Ns}=\mathrm{p}<0.05$.

The findings demonstrate that the attitudinal structure behind welfare conditionality bears remarkable resemblance to the one underlying welfare generosity. This implies that future research in the relatively novel field of public opinion concerning activation policies might not have to 'reinvent the wheel', but is to a large extent able to reproduce the causal logics that have been established in the long-standing social rights literature. However, the results also show that the respective models for explaining the two types of welfare attitudes are not exact mirror images of one another. First, the models for social rights and obligations differ notably with respect to which variable has the greatest explanatory power. Whereas people's adherence to the work ethic and the deservingness criterion of attitude appear to be most decisive in shaping conditionality, it is egalitarianism that has the most profound impact on generosity. Despite all the similarities, citizens thus appear to apply a somewhat different logic in forming opinions about social rights compared with attitudes towards social obligations. A second disparity is that the proportion of explained variance was much higher (nearly twice as high) in the conditionality models than in the generosity models. This observation suggests that self-interest and ideational beliefs (deservingness beliefs in particular) are better at explaining individual differences in welfare conditionality than in welfare generosity. Some caution is warranted, however, given that generosity was operationalised with a single item, while conditionality was measured as a composite score based on multiple items. As a result, our measurement of conditionality was less prone to random measurement error, and higher $R$-squared values could be obtained. However, another plausible interpretation is that the higher explained variance in case of conditionality is due to the fact that, compared with the long-established, institutionalised welfare policies that focus on social rights, activating welfare policies is relatively novel in Western Europe, and is accordingly more intensively debated in public discourse, and also still structured more strongly along the lines of social-structural cleavages and ideological divides.

\section{Acknowledgements}

This study was made possible by grants from KU Leuven research council (OT/13/30), the Belgian National Lottery and the National Science Foundation FWO-Vlaanderen (Grant Number G.0769.15).

\section{References}

Abts, K., Swyngedouw, M., Meuleman, B., Baute, S., Galle, J., \& Gaasendam, C. (2015). Belgian National Elections Study 2014. Codebook: Questions and frequency tables. Leuven: KU Leuven.

Achterberg, P., van der Veen, R., \& Raven, J. (2014). The ideological roots of the support for welfare state reform: 
Support for distributive and commodifying reform in The Netherlands. International Journal of Social Welfare, 23(2), 215-226.

Alston, J. P. \& Dean, K. I. (1972). Socioeconomic factors associated with attitudes toward welfare recipients and the causes of poverty. Social Service Review, 46(1), 13-23.

Appelbaum, L. (2001). The influence of perceived deservingness on policy decisions regarding aid to the poor. Political Psychology, 22(3), 419-442.

Arts, W. \& Gelissen, J. (2001). Welfare states, solidarity and justice principles: Does the type really matter? Acta Sociologica, 44(4), 283-299.

Bean, C. \& Papadakis, E. (1998). A comparison of mass attitudes towards the welfare state in different institutional regimes, 1985-1990. International Journal of Public Opinion Research, 10(3), 211-236.

Betzelt, S. \& Bothfeld, S. (Eds.) (2011). Activation and labour market reforms in Europe: Challenges to social citizenship. Basingstoke: Palgrave MacMillan.

Buss, C., Ebbinghaus, B., \& Naumann, E. (2017). Making deservingness of the unemployed conditional. Changing public support for the conditionality of unemployment benefits across Europe. In: W. van Oorschot, B. Meuleman, T. Reeskens, \& F. Roosma (Eds.), The social legitimacy of targeted welfare: Attitudes to welfare deservingness (pp. 167-185). Cheltenham: Edward Elgar Publishing.

Cusack, T., Iversen, T., \& Rehm, P. (2006). Risks at work: The demand and supply sides of government redistribution. Oxford Review of Economic Policy, 22(3), 365-389.

Eardley, T., Saunders, P., \& Evans, C. (2000). Community attitudes towards unemployment, activity testing and mutual obligation. Australian Bulletin of Labour, 26(3), 211-235.

Feldman, S. \& Zaller, J. (1992). The political culture of ambivalence: Ideological responses to the welfare state. American Journal of Political Science, 36(1), 268-307.

Furaker, B. \& Blomsterberg, M. (2003). Attitudes towards the unemployed. An analysis of Swedish survey data. International Journal of Social Welfare, 12(3), 193-203.

Furnham, A. (1983). Attitudes toward the unemployed receiving social security benefits. Human Relations, 36(2), $135-150$.

Gilens, M. (1999) Why Americans hate welfare: Race, media and the politics of anti-poverty policy. Chicago: The University of Chicago Press.

Hasenfeld, Y. \& Rafferty, J. (1989). The determinants of public attitudes toward the welfare state. Social Forces, 67(4), 1027-1048.

Hemerijck, A. C. \& Marx, I. (2010). Continental welfare at a crossroads: The choice between activation and minimum income protection in Belgium and the Netherlands. In: B. Palier (Ed.), A long goodbye to Bismarck? The politics of welfare reform in continental Europe (pp. 129-155). Amsterdam: Amsterdam University Press.

Houtman, D. (1997). Welfare state, unemployment, and social justice: Judgments on the rights and obligations of the unemployed. Social Justice Research, 10(3), 267-288.

Jaeger, M. M. (2006). What makes people support public responsibility for welfare provision: Self-interest or political ideology? A longitudinal approach. Acta Sociologica, 49(3), 321-338

Jaeger, M. M. (2008). Does left - right orientation have a causal effect on support for redistribution? Causal analysis with cross-sectional data using instrumental variables. International Journal of Public Opinion Research, 20(3), 363-374.

Jeene, M. \& van Oorschot, W. (2013). The relative deservingness of the unemployed in the eyes of the European public. In: L. Halman \& W. Arts (Eds.), Value contrasts and consensus in present-day Europe: Painting Europe's moral landscapes (pp. 95-116). The Hague: Brill.
Jeene, M. \& van Oorschot, W. (2015). The social legitimacy of the activating welfare state: Public opinion on work obligations \& welfare rights of benefit claimants. In: M. Jeene (Ed.), Who should get what and why, under which conditions? Descriptions and explanations of public deservingness opinions (pp. 114-137). Ridderkerk: Ridderprint.

Kallio, J. \& Kouvo, A. (2015). Street-level bureaucrats' and the general public's deservingness perceptions of social assistance recipients in Finland. Social Policy and Administration, 49(3), 316-334.

Kangas, O. E. (1997). Self-interest and the common good: The impact of norms, selfishness and context in social policy opinions. The Journal of Socio-Economics, 26(5), 475-494.

Kootstra, A. (2016). (Un)deserving welfare claimants in Britain and the Netherlands: Examining the role of ethnicity and migration status using a vignette experiment. European Sociological Review, 32(3), 325-328.

Kvist, J. (2002). Changing rights and obligations in unemployment insurance. In: R. Sigg \& C. Behrendt (Eds.), Social security in the global village (pp. 227-247). New Brunswick: Transaction Publishers.

Larsen, C. A. (2002). Unemployment and stigmatization: The dilemma of the welfare state. In: J. Goul Andersen \& K. Halvorsen (Eds.), Unemployment and citizenship: Marginalisation and integration in the Nordic countries (pp. 55-72). Bristol: Policy Press Co.

Larsen, C. A. (2006). The institutional logic of welfare attitudes. How welfare regimes influence public support. Aldershot: Ashgate Publishing Ltd.

Larsen, C. A. (2008). The political logic of labour market reforms and popular images of target groups. Journal of European Social Policy, 18(1), 50-63.

Likki, T. \& Staerklé, C. (2015). Welfare support in Europe: Interplay of dependency culture beliefs and meritocratic contexts. International Journal of Public Opinion Research, 27(1), 138-153.

Linos, K. \& West, M. (2003). Self-interest, social beliefs, and attitudes to redistribution: Re-addressing the issue of cross-national variation. European Sociological Review, 19(4), 393-409.

Maassen, G. \& De Goede, M. (1989). Public opinion about unemployed people in the period 1975-1995; the case of the Netherlands. The Netherlands' Journal of Social Sciences, 25(2), 97-113.

Meuleman, B., Roosma, F., \& van Oorschot, W. (2017). Evaluating the fruitfulness of deservingness theory. In: W. van Oorschot, F. Roosma, B. Meuleman, \& T. Reeskens (Eds.), The social legitimacy of targeted welfare. Attitudes to welfare deservingness (pp. 335-351). Cheltenham: Edward Elgar Publishing.

Murray, C. (1984). Losing ground: American social policy 1950-1980. New York: Basic Books.

Petersen, M. B. (2012). Social welfare as small-scale help: Evolutionary psychology and the deservingness heuristic. American Journal of Political Science, 56(1), 1-16.

Roosma, F. \& Jeene, M. (2017). The deservingness logic applied to public opinions concerning work obligations for benefit claimants. In: W. van Oorschot, B. Meuleman, T. Reeskens, \& F. Roosma (Eds.), The social legitimacy of targeted welfare: Attitudes to welfare deservingness (pp. 189-205). Cheltenham: Edward Elgar Publishing.

Saunders, P. (2002). Mutual obligation, participation and popularity: Social security reform in Australia. Journal of Social Policy, 31(1), 21-38.

Slothuus, R. (2007). Framing deservingness to win support for welfare state retrenchment. Scandinavian Political Studies, 30(3), 323-344.

Statistics Belgium. (2014). Brussels. Retrieved from www.statbel.fgov.be/ 
Svallfors, S. (2013). Government quality, egalitarianism, and attitudes to taxes and social spending: A European comparison. European Political Science Review, 5(3), 363-380.

Taylor-Gooby, P. (2011). Security, equality and opportunity: Attitudes and the sustainability of social protection. Journal of European Social Policy, 21(2), 150-163.

van Oorschot, W. (2006). Making the difference in social Europe: Deservingness perceptions among citizens of European welfare states. Journal of European Social Policy, 16(1), 23-42.

van Oorschot, W. \& Meuleman, B. (2012). Welfare performance and welfare support. In: S. Svallfors (Ed.), Contested welfare states: Welfare attitudes in Europe and beyond (pp. 25-57). Stanford: Stanford University Press.

van Oorschot, W., Reeskens, T. and Meuleman, B. (2012). Popular perceptions of welfare state consequences: A multilevel, cross-national analysis of 25 European countries. Journal of European Social Policy, 22(2), 181-197.

van Oorschot, W. \&Roosma, F. (2017). The social legitimacy of targeted welfare and welfare deservingness. In: W. van Oorschot, F. Roosma, B. Meuleman, \& T. Reeskens (Eds.), The social legitimacy of targeted welfare: Attitudes to welfare deservingness (pp. 3-33). Cheltenham: Edward Elgar Publishing. 


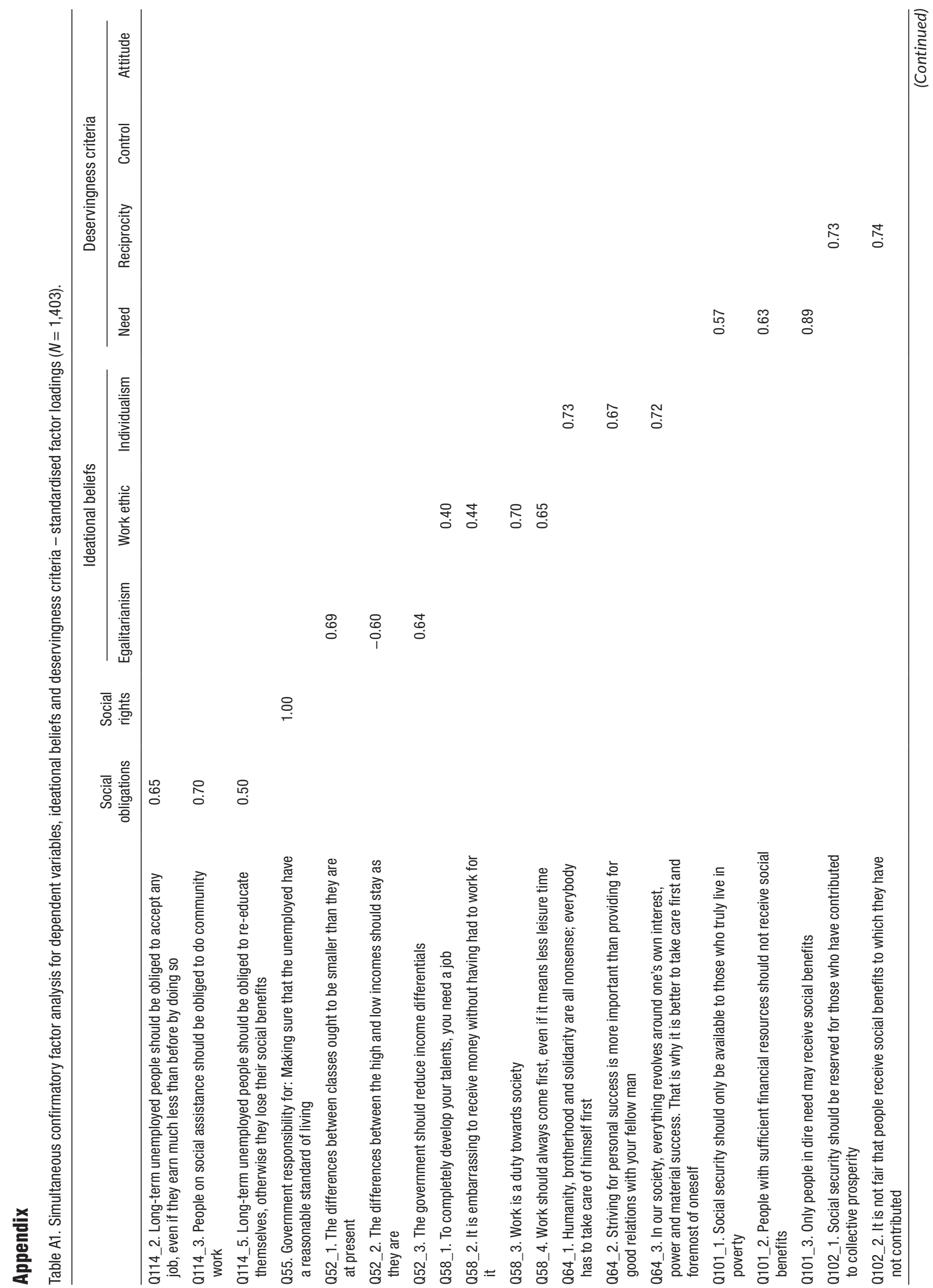




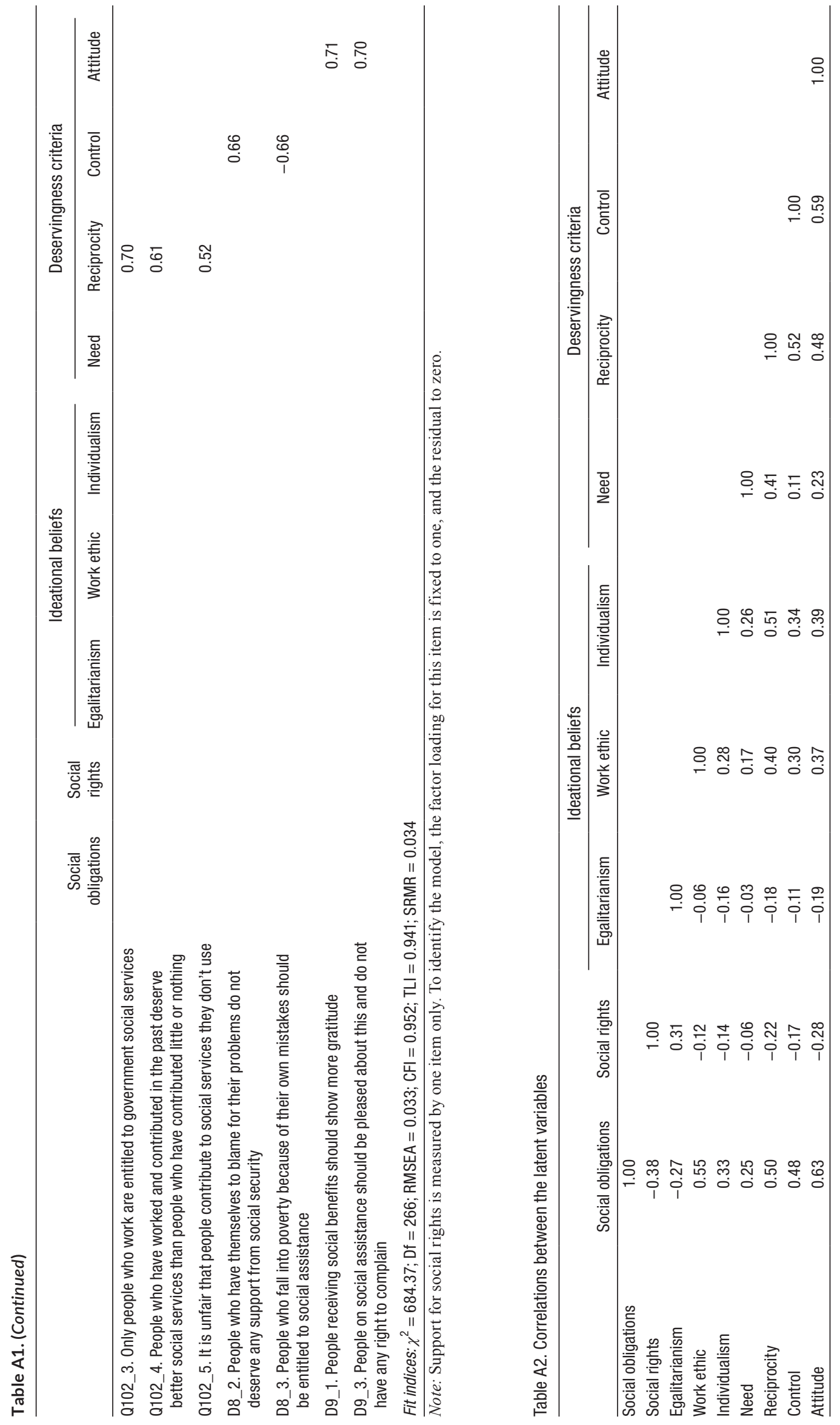

